\title{
DILATATION AND UNFOLDING OF THE AORTA IN A JAMAICAN POPULATION
}

\author{
BY \\ K. L. STUART, W. E. MIALL, J. A. TUllOCH, AND D. E. CHRISTIAN \\ From the University College of the West Indies, and the Pneumoconiosis Research Unit, Llandough Hospital, Penarth, \\ South Wales \\ Received February 15, 1962
}

In the year 1959-60 a team from the Medical Research Council's Pneumoconiosis Research Unit, in collaboration with the Ministry of Health, Jamaica, undertook a chest X-ray survey of a rural population in Jamaica with the primary objective of determining the prevalence of pulmonary tuberculosis (Miall and Rerrie, 1961). During the reading of the $70 \mathrm{~mm}$. films, we were struck by the high prevalence of aortic and other cardiovascular abnormalities. As the survey had been carried out in a geographically defined population in which over 90 per cent of subjects were X-rayed, it was possible to compare the characteristics of those with radiologically detected cardiovascular abnormalities with those of an age and sex matched control group drawn by random methods from those subjects in the same population who were free of such abnormalities. This paper reports the results of this comparison.

It is generally accepted that cardiovascular screening by mass radiography is a useful and practical procedure and the technique has been widely used, particularly in the United States (Thompson et al., 1961). Cochrane (1960) has reported the results of such a survey from Barbados, and Wattley (1960) from Trinidad. This is, as far as we know, the first time that an attempt has been made to use a control group to determine the ætiology of the abnormalities.

\section{The Population SAMPles}

The rural area selected for this survey is that surrounding the village of Lawrence Tavern, some twenty miles inland from Kingston. The population, comprising about 8500 people, is relatively stable, co-operative, and representative of rural populations in the island; it is thus well suited to epidemiological studies designed to measure the prevalence of common diseases in the community. Prevalence rates of parasitic infestation (Johnston, 1959), hypertension (Miall et al., 1961), and bacteriuria (Kass et al., 1961) have been determined previously.

The terrain is hilly and often precipitous: the main occupation for both men and women is peasant farming - the cultivation of produce for home consumption and for sale in the local markets. For men there is also a variety of casual occupations, most of which involve heavy manual labour.

For most of the working day, exposure to the sun and rain is the rule and long distances are often covered on foot. Nutritional surveys have shown that the diet is, in general, deficient in fats and protein and relatively high in carbohydrates, although fluctuations in the seasonal or economic availability of certain foodstuffs may produce wide swings in dietary levels. This rugged and somewhat marginal existence is as characteristic for this area as it is for many other parts of Jamaica and most of the other West Indian islands. 
The populations, defined by private census, included 2172 men and 2616 women over the age of 15 years (Table I). Of these, 90.5 per cent of the men and 91.5 per cent of the women were

TABLE I

Chest X-RAY SURVey, LAWRence TAVERn 1959-60

\begin{tabular}{|c|c|c|c|c|c|c|}
\hline \multirow{2}{*}{$\begin{array}{l}\text { Age } \\
\text { group }\end{array}$} & \multicolumn{3}{|c|}{ Men } & \multicolumn{3}{|c|}{ Women } \\
\hline & $\mathrm{X}$-rayed & Lapses & Total & X-rayed & Lapses & Total \\
\hline $\begin{array}{c}15- \\
20- \\
25- \\
30- \\
35- \\
40- \\
45- \\
50- \\
55- \\
60- \\
65- \\
70- \\
75- \\
80- \\
85- \\
90- \\
95- \\
100-\end{array}$ & $\begin{array}{c}292 \\
199 \\
156 \\
175 \\
170 \\
200 \\
168 \\
195 \\
155 \\
107 \\
66 \\
42 \\
25 \\
11 \\
1 \\
3 \\
-\end{array}$ & $\begin{array}{r}27 \\
21 \\
29 \\
21 \\
13 \\
19 \\
14 \\
10 \\
11 \\
13 \\
9 \\
5 \\
7 \\
6 \\
1 \\
1 \\
-\end{array}$ & $\begin{array}{c}319 \\
220 \\
185 \\
196 \\
183 \\
219 \\
182 \\
205 \\
166 \\
120 \\
75 \\
47 \\
32 \\
17 \\
2 \\
4 \\
-\end{array}$ & $\begin{array}{c}356 \\
260 \\
261 \\
222 \\
210 \\
207 \\
206 \\
199 \\
158 \\
110 \\
89 \\
57 \\
35 \\
20 \\
3 \\
- \\
-\end{array}$ & $\begin{array}{r}39 \\
24 \\
15 \\
20 \\
13 \\
9 \\
11 \\
14 \\
8 \\
14 \\
10 \\
12 \\
15 \\
7 \\
7 \\
2 \\
2 \\
1\end{array}$ & $\begin{array}{r}395 \\
284 \\
276 \\
242 \\
223 \\
216 \\
217 \\
213 \\
166 \\
124 \\
99 \\
69 \\
50 \\
27 \\
10 \\
2 \\
2 \\
1\end{array}$ \\
\hline Total & $\begin{array}{c}1965 \\
(90 \cdot 5 \%)\end{array}$ & $\begin{array}{c}207 \\
(9 \cdot 5 \%)\end{array}$ & $\begin{array}{c}2172 \\
(100.0 \%)\end{array}$ & $\begin{array}{c}2393 \\
(91.5 \%)\end{array}$ & $\begin{array}{l}223 \\
(8 \cdot 5 \%)\end{array}$ & $\begin{array}{l}2616 \\
(100 \%)\end{array}$ \\
\hline
\end{tabular}

X-rayed. Cardiovascular abnormalities were largely confined to those over the age of 35 ; as the sizes of the age groups fall off rapidly from 65 upwards, to avoid the major biases that are introduced by survivorship, we have limited the investigation to those aged 35-64 years. Errors in stated age are considerable in Jamaica (Miall et al., 1961); age statements were checked against birth certificates for only about half of the subjects forming these groups, but any errors introduced by inaccurate ages are likely to affect both groups equally.

\section{METHODS}

Each chest X-ray was read independently by four observers. Cardiovascular abnormality was only accepted where agreement was present between three of the four observers. Similarly, agreement between three of the four observers was necessary for defining those without cardiovascular abnormality. All subjects who showed cardiovascular abnormalities radiologically were asked to attend a special clinic in the area for full clinical examination. Age and sex matched control groups without cardiovascular abnormalities were examined similarly. The control groups consisted of 15 subjects of each sex in the 35-44 year age group, 30 in the 45-54 year age group, and 60 in the 55-64 year age group.

A total of 171 of the 198 subjects $(86 \%)$ with cardiovascular abnormalities showed some degree of dilatation of the aorta, with or without other lesions, and this was by far the commonest single abnormality noted and it was often extreme. In view of this high prevalence an attempt was made to classify the aortic dilatation as slight, moderate, and severe. This classification was based on the agreed readings of two of the observers; the criteria were descriptive and no attempt was made at exact measurement. Fig. 1-3 are characteristic examples of how the films were classified. In this study, we have included only those affected subjects who showed aortic dilatation, and have omitted other cardiological disease. 


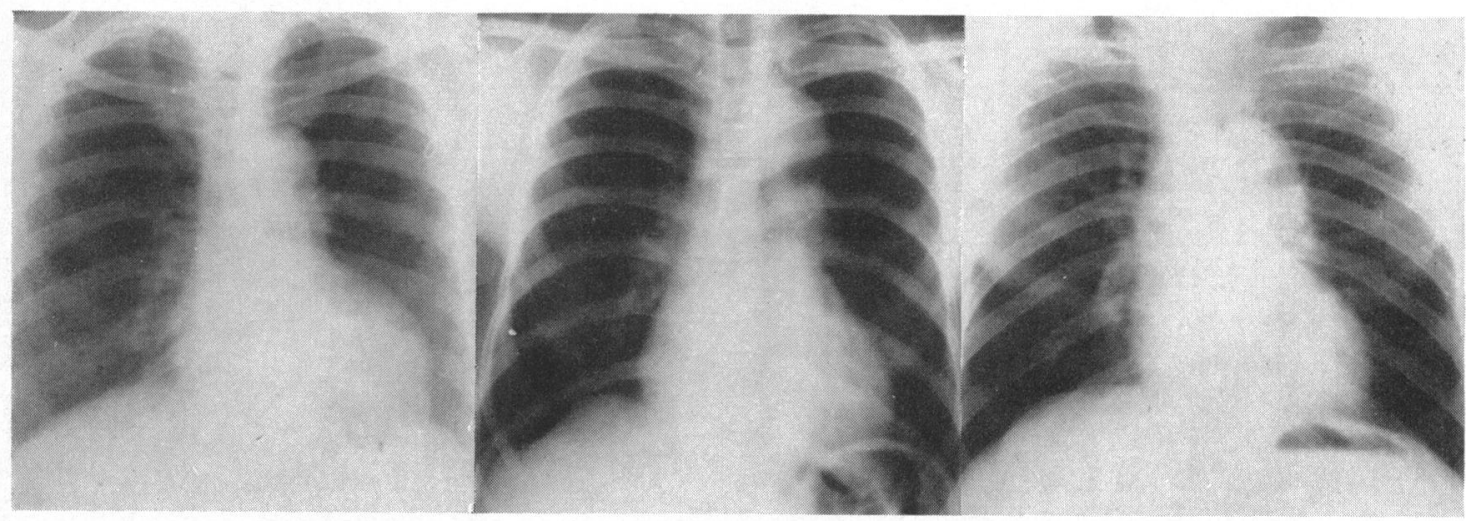

FIG. 1.-X-ray of woman aged 60 with slight aortic dilatation.
Fig. 2.-X-ray of man aged 51 show- Fig. 3.-X-ray of man aged 52 showing moderate aortic dilatation. ing severe aortic dilatation.

Blood was drawn from each subject for biochemical and hæmatological investigations. These included hæmoglobin and serum cholesterol determinations and serological tests for treponemal infection. Hæmoglobin was estimated by the Sahli method.

The Wassermann and Price precipitation reactions were carried out by the Public Health Laboratory Service, Cardiff; the V.D.R.L. test was done in the serological laboratory of the University College of the West Indies. Any subject with two or more positive results of the Wassermann, Price precipitation reaction and V.D.R.L. determinations was considered as showing a positive result.

\section{RESULTS}

Table II shows the number and percentage of all subjects with aortic dilatation on X-ray. Three women and two men from the affected group did not report for clinical evaluation and are not included in this study; 15 women and 9 men from the control group refused investigations.

TABLE II

Cardiovascular Abnormalities in Radiographs of Lawrence Tavern Population Aged 35-64 Years

\begin{tabular}{|c|c|c|c|c|c|c|c|c|}
\hline \multirow{2}{*}{ S } & \multirow{2}{*}{\multicolumn{2}{|c|}{ Sex }} & \multirow{2}{*}{ Age group } & \multirow{2}{*}{$\begin{array}{l}\text { Number } \\
\text { X-rayed }\end{array}$} & \multirow{2}{*}{$\begin{array}{c}\text { Number with CVS } \\
\text { abnormalities }\end{array}$} & \multicolumn{3}{|c|}{ Subjects with dilated aortas } \\
\hline & & & & & & Number & $\begin{array}{c}\text { Percentage with } \\
\text { CVS abnormalities }\end{array}$ & $\begin{array}{l}\text { Percentage } \\
\text { X-rayed }\end{array}$ \\
\hline Men & . & .. & $\begin{array}{c}35-44 \\
45-54 \\
55-64 \\
\text { Total }\end{array}$ & $\begin{array}{l}370 \\
363 \\
262 \\
995\end{array}$ & $\begin{array}{l}15 \\
23 \\
59 \\
97\end{array}$ & $\begin{array}{r}8 \\
17 \\
54 \\
79\end{array}$ & $\begin{array}{l}53 \cdot 3 \\
73 \cdot 9 \\
91 \cdot 5 \\
81 \cdot 4\end{array}$ & $\begin{array}{r}2 \cdot 2 \\
4 \cdot 7 \\
20 \cdot 6 \\
7 \cdot 9\end{array}$ \\
\hline Women & & . & $\begin{array}{r}35-44 \\
45-54 \\
55-64 \\
\text { Total }\end{array}$ & $\begin{array}{r}417 \\
405 \\
268 \\
1090\end{array}$ & $\begin{array}{r}9 \\
41 \\
56 \\
106\end{array}$ & $\begin{array}{r}8 \\
32 \\
52 \\
92\end{array}$ & $\begin{array}{l}88.9 \\
78.0 \\
92.9 \\
86.8\end{array}$ & $\begin{array}{r}1.9 \\
7.9 \\
19.4 \\
8.4\end{array}$ \\
\hline
\end{tabular}

Clinical Findings. The most common finding on clinical examination of the affected group was hypertension. In all age groups, these subjects showed considerably higher levels of arterial pressure than did the controls (Table III); in the younger age groups, aortic dilatation was associated with more pronounced elevations of pressure above the means for controls than in the older age range. 
TABLE III

Mean Blood Pressure Levels in Subjects with Aortic Dilatation*

\begin{tabular}{|c|c|c|c|c|c|c|c|c|c|c|}
\hline \multirow{2}{*}{$\begin{array}{l}\text { Age } \\
\text { group }\end{array}$} & \multicolumn{5}{|c|}{ Men } & \multicolumn{5}{|c|}{ Women } \\
\hline & Subjects & & Controls & & $\begin{array}{l}\text { Mean B.P. } \\
\text { increment }\end{array}$ & Subjects & & Controls & & $\begin{array}{l}\text { Mean B.P. } \\
\text { increment }\end{array}$ \\
\hline \multirow[t]{2}{*}{$35-44$} & 164.0 & & $138 \cdot 8$ & & $25 \cdot 2$ & 193.0 & & 137.0 & & $56 \cdot 0$ \\
\hline & $105 \cdot 9$ & $8^{*}$ & $82 \cdot 5$ & 12 & $\overline{23.4}$ & $\overline{117 \cdot 5}$ & 8 & $87 \cdot 6$ & 11 & $\overline{29.9}$ \\
\hline \multirow[t]{2}{*}{$45-54$} & $165 \cdot 0$ & & $142 \cdot 6$ & & $22 \cdot 4$ & $189 \cdot 3$ & & 143.5 & & $45 \cdot 8$ \\
\hline & $100 \cdot 4$ & 17 & $85 \cdot 4$ & 26 & $15 \cdot 0$ & 112.0 & 32 & 89.0 & 23 & $23 \cdot 0$ \\
\hline \multirow[t]{2}{*}{$55-64$} & $\frac{163 \cdot 6}{07 \cdot 0}$ & & $\frac{145 \cdot 6}{0.5}$ & & $\frac{18 \cdot 0}{12.5}$ & $\frac{191 \cdot 1}{11 \cdot 6}$ & & $\frac{168 \cdot 8}{0.9}$ & & $\frac{22 \cdot 3}{15 \cdot}$ \\
\hline & & 54 & & 58 & & & 52 & & 56 & \\
\hline
\end{tabular}

* Number of subjects in italics.

In each age group, in affected and control subjects, the mean pressures were higher in women than in men. The blood pressure levels showed a tendency to rise in proportion to the degree of aortic dilatation (Table IV).

TABLE IV

Mean Blood Pressure Levels in Relation to Degree of Aortic Dilatation*

\begin{tabular}{|c|c|c|c|c|c|c|c|c|c|c|c|c|}
\hline \multicolumn{4}{|c|}{ Sex } & \multirow{2}{*}{$\frac{\text { Age group }}{35-54}$} & \multirow{3}{*}{$\frac{\text { Slight } \uparrow}{\frac{162 \cdot 3}{100 \cdot 6}}$} & \multicolumn{2}{|r|}{ Moderate $\dagger$} & \multicolumn{2}{|r|}{ Severe $\dagger$} & \multicolumn{3}{|c|}{ Controls } \\
\hline \multirow[t]{4}{*}{ Men } & & & \multirow[t]{4}{*}{.. } & & & \multirow{2}{*}{\multicolumn{2}{|c|}{$\frac{172 \cdot 5}{106 \cdot 6}$}} & \multirow{2}{*}{\multicolumn{2}{|c|}{$\frac{130}{86}$}} & \multicolumn{3}{|c|}{$141 \cdot 4$} \\
\hline & & & & & & & & & & 1 & & 38 \\
\hline & & & & \multirow[t]{2}{*}{$55-64$} & $\frac{162 \cdot 9}{06}$. & \multirow{2}{*}{\multicolumn{2}{|c|}{$\frac{164 \cdot 1}{98}$}} & & \multirow{2}{*}{$\frac{165}{95}$} & \multicolumn{3}{|c|}{$\frac{145 \cdot 6}{84 \cdot 5}$} \\
\hline & & & & & & & & 30 & & 1 & & 58 \\
\hline \multirow[t]{4}{*}{ Women } & \multirow[t]{4}{*}{.. } & \multirow[t]{4}{*}{$\ldots$} & \multirow[t]{4}{*}{.. } & \multirow[t]{2}{*}{$35-54$} & $183 \cdot 3$ & \multirow{2}{*}{\multicolumn{2}{|c|}{$\frac{198}{115 \cdot 3}$}} & & \multirow{2}{*}{$\frac{216}{140}$} & \multirow{2}{*}{\multicolumn{3}{|c|}{$\frac{144 \cdot 7}{88 \cdot 5}$}} \\
\hline & & & & & $110 \cdot 4$ & & & 16 & & & & \\
\hline & & & & \multirow[t]{2}{*}{$55-64$} & $\frac{199}{110.1}$ & & $\frac{203}{100}$ & & \multirow{2}{*}{$\frac{205 \cdot 7}{123 \cdot 6}$} & \multicolumn{3}{|c|}{$\frac{168 \cdot 8}{95 \cdot 3}$} \\
\hline & & & & & & 15 & & 30 & & 7 & & 56 \\
\hline
\end{tabular}

* Number of subjects in italics.

$\dagger$ Degree of aortic dilatation.

Aortic regurgitation was found in 16 of the 79 affected men $(20 \%)$ and in 6 of the 92 affected women $(7 \%)$. This difference in the prevalence of aortic regurgitation between the two sexes is significant $(p<0.01)$ (Table V). Mean blood pressure levels in these subjects were 156/90 in men and $189 / 106$ in women. None showed evidence of cardiac failure. Four controls had aortic regurgitation.

Cardiac failure was present in only two subjects; both were hypertensive and, in one of these, the hæmoglobin level of $4.6 \mathrm{~g}$. per $100 \mathrm{ml}$. was found to be due to hookworm infestation. Severe anæmia was indeed more often responsible for cardiac symptoms than was the aortic lesion. 
TABLE V

Details of Subjects with Isolated Aortic Regurgitation

\begin{tabular}{|c|c|c|c|}
\hline Total number of subjects & Men & Women & Total \\
\hline Number with aortic regurgitation .. & $\begin{array}{l}79 \\
16(10 \%)\end{array}$ & 92 & $\begin{array}{l}171 \\
22\end{array}$ \\
\hline 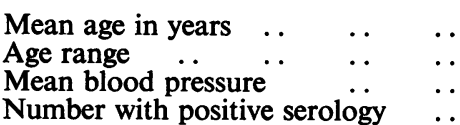 & $\begin{array}{l}55 \\
43-64 \\
166-90 \\
2(13 \%)\end{array}$ & $\begin{array}{l}55 \cdot 5 \\
40-64 \\
189 / 106 \\
1\left(17^{\circ}\right)\end{array}$ & $3\left(14^{\circ} \%\right)$ \\
\hline
\end{tabular}

In spite of the high prevalence of arterial hypertension, symptoms and signs of hypertensive vascular disease were inconspicuous. None of those found with aortic regurgitation showed evidence of cardiac failure. Clinical deterioration is rapid in cases of aortic regurgitation following the onset of cardiac failure, and this would probably be accelerated in areas like Lawrence Tavern, so few patients in failure would be expected.

Serological Findings. The results of serological tests for treponemal infection were similar in the affected subjects and their controls (Table VI). Twenty-two women (24\%) in the affected group

TABLE VI

Serology of Subjects with Aortic Dilatation and of Controls

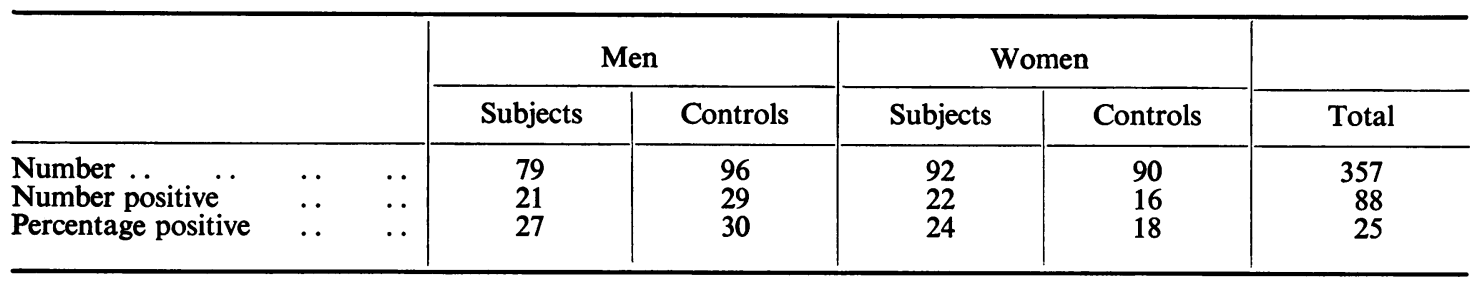

and $16(18 \%)$ in the control group gave positive results by the criteria adopted. Corresponding figures for men were 27 per cent and 30 per cent respectively. No significant correlation could therefore be demonstrated between the presence of aortic dilatation and positive serological tests.

Of the 22 subjects with aortic regurgitation, $3(14 \%)$ gave positive serological results (Table V). Furthermore, no significant difference in arterial pressure was found between those with positive and those with negative serological tests (Table VII).

Hamoglobin and Serum Cholesterol Levels. Mean hæmoglobin levels were similar in subjects and controls, averaging $11.5 \mathrm{~g}$. per $100 \mathrm{ml}$. for women and $12.2 \mathrm{~g}$. for men. These levels are lower than English or North American averages. They correspond closely to those found in St. Kitts, another West Indian island (Stuart et al., 1961) and probably reflect moderate protein undernutrition. However, other causes of anæmia, such as sickle cell disease and hookworm infestation, were not evaluated in our survey. Mean serum cholesterol values were slightly higher in those with aortic dilatation than in the control group. The difference, however, was not statistically significant.

\section{Discussion}

The integrity of the aortic wall may be threatened by a wide variety of factors, many intrinsic to the aorta itself. These include degenerative changes such as atheroma and medial degeneration, infective lesions as in syphilis, and hereditary disorders as in Marfan's syndrome. All are commonly associated with aneurysm formation and in all the area of predominant involvement is the thoracic aorta; this suggests that localization to the thoracic aorta may be dictated by circulatory and other mechanical factors, and not entirely by the nature of the lesion. 
TABLE VII

Mean Blood Pressure LeVels in Relation to Serology

\begin{tabular}{|c|c|c|c|c|c|c|c|}
\hline Sex & & Age & Serology & Subjects & No. & Controls & No. \\
\hline \multirow{3}{*}{ Men } & \multirow{3}{*}{.. } & $35-44$ & $\begin{array}{l}\text { Positive } \\
\text { Negative }\end{array}$ & $\begin{array}{l}\frac{153 \cdot 5}{97} \\
\frac{167 \cdot 5}{108 \cdot 8}\end{array}$ & 2 & $\begin{array}{c}- \\
\frac{138 \cdot 8}{82 \cdot 5}\end{array}$ & - \\
\hline & & $45-54$ & $\begin{array}{l}\text { Positive } \\
\text { Negative }\end{array}$ & $\begin{array}{l}\frac{163 \cdot 4}{104} \\
\frac{165 \cdot 6}{98.9}\end{array}$ & $\begin{array}{r}5 \\
12\end{array}$ & $\begin{array}{l}\frac{146 \cdot 9}{88 \cdot 3} \\
\frac{140 \cdot 2}{84 \cdot 2}\end{array}$ & 18 \\
\hline & & $55-64$ & $\begin{array}{l}\text { Positive } \\
\text { Negative }\end{array}$ & $\begin{array}{l}\frac{165 \cdot 6}{97 \cdot 6} \\
\frac{162 \cdot 9}{96 \cdot 8}\end{array}$ & $\begin{array}{l}14 \\
40\end{array}$ & $\begin{array}{l}\frac{146 \cdot 8}{84} \\
\frac{145 \cdot 1}{85}\end{array}$ & $\begin{array}{l}21 \\
37\end{array}$ \\
\hline \multirow{3}{*}{ Women } & \multirow{3}{*}{.. } & $35-44$ & $\begin{array}{l}\text { Positive } \\
\text { Negative }\end{array}$ & $\begin{array}{l}\frac{200}{120} \\
\frac{192}{117 \cdot 1}\end{array}$ & $\begin{array}{l}1 \\
7\end{array}$ & $\begin{array}{l}\frac{150}{108} \\
\frac{135 \cdot 7}{85 \cdot 6}\end{array}$ & 10 \\
\hline & & $45-54$ & $\begin{array}{l}\text { Positive } \\
\text { Negative }\end{array}$ & $\begin{array}{l}\frac{169 \cdot 2}{100 \cdot 2} \\
\frac{196 \cdot 4}{115 \cdot 9}\end{array}$ & $\begin{array}{r}8 \\
24\end{array}$ & $\begin{array}{l}\frac{151 \cdot 8}{94} \\
\frac{144 \cdot 8}{87 \cdot 7}\end{array}$ & $\begin{array}{r}5 \\
18\end{array}$ \\
\hline & & $55-64$ & $\begin{array}{l}\text { Positive } \\
\text { Negative }\end{array}$ & $\begin{array}{l}\frac{183 \cdot 2}{108 \cdot 7} \\
\frac{193 \cdot 8}{111 \cdot 3}\end{array}$ & $\begin{array}{l}13 \\
39\end{array}$ & $\begin{array}{l}\frac{178 \cdot 8}{97 \cdot 7} \\
\frac{166 \cdot 6}{94 \cdot 8}\end{array}$ & $\begin{array}{l}10 \\
46\end{array}$ \\
\hline
\end{tabular}

Unless environmental factors and their consequences can be evaluated, conclusions about the racial determinants of disease must be misleading. In Jamaica, the possible rôles of such factors as infection, exposure, malnutrition, and physical exertion should clearly be considered. It would seem likely, for instance, that the probability of developing an aortic aneurysm and, once developed, its progression to aortic regurgitation and congestive cardiac failure, would be very different in an office worker in London and a labourer in rural Jamaica, even if they were both equally predisposed.

In this study of aortic dilatation in country people in Jamaica, we have investigated the role of circulatory factors and treponemal infection and hæmoglobin and cholesterol levels. The homogeneity of occupations for both sexes makes evaluation of the importance of factors involved in physical activity almost impossible.

The Role of Hypertension. We have found that arterial hypertension relates to both the presence of aortic dilatation and to its degree (Table III and IV). The prevalence of aortic dilatation increases with age, as does arterial pressure and is higher in women than in men, a finding which is consistent with the higher blood pressure levels found in women. In subjects with aortic dilatation blood pressure levels, though conspicuously raised in comparison with those with normal aortas, did not show a comparable increase in pressure with age. Pressures were, in fact, higher in the $35-44$ than in the 55-64 age group in both sexes. It is suggested that in the younger age groups, in 
whom degenerative or infective aortic changes would be less common, higher arterial pressures are necessary for the production of aortic dilatation.

Hypertension itself, however, does not usually in whites cause the degree of aortic involvement seen in this survey. The possibility that hypertension, when associated with aortic damage, is responsible for aortic dilatation, is suggested by the higher prevalence of severe changes in those with hypertension and a positive serological test (Table VIII).

TABLE VIII

Percentage Showing Moderate or Marked Aortic Dilatation by Blood Pressure and Serology

\begin{tabular}{ll|c|c}
\hline & \multicolumn{2}{|c}{ Diastolic pressure } \\
\cline { 2 - 4 } & & $>110 \mathrm{~mm} . \mathrm{Hg}$ & $<110 \mathrm{~mm} . \mathrm{Hg}$ \\
\hline Serology positive & $\ldots$ & $76 \%$ & $55 \%$ \\
Serology negative & $\cdots$ & $56 \%$ & $49 \%$ \\
\hline
\end{tabular}

Treponematosis and its Relationship to Aortic Dilatation and Arterial Pressure. The overall rates for positive serological tests for treponemal infection in this population are high when compared with rates for white races (Beerman $e$ t al., 1961). With the criteria for positivity we adopted, the rates were about 25 per cent positive. A prevalence of 30 per cent has been given for negroes in Alabama (Beerman et al., 1961). Grant (1956) has shown that positive V.D.R.L. determinations range from 15 to 40 per cent in different parts of Jamaica.

It is impossible in a Jamaican population to equate a positive test of this kind with syphilitic infection, mainly because serological tests do not differentiate between syphilis and other treponemal infections, such as yaws and pinta. However, whatever the explanation of these observations, our findings seem to show that in rural Jamaica there is no demonstrable correlation between a positive reaction and aortic dilatation or aortic regurgitation in the general population.

The possibility remains that aortic damage due to treponemal infection may be an important factor in the production of the aortic dilatation reported in this study. The high rates of positive serological tests, however, in both subjects and controls would suggest (1) that the population at risk is much larger than the incidence of aortic dilatation would indicate, and (2) that, in the population at risk, some other factor, probably hypertension, determines the development and degree of aortic dilatation.

If the aortic damage were due to previous treponemal infection, one would expect the moderate or severe degrees of aortic dilatation to be most common in those with hypertension and a positive serology and least common in those without either of these. Table VIII shows the percentage with hypertension $(110 \mathrm{~mm}$. Hg diastolic and above) and others who show moderate and severe degrees of aortic dilatation according to their serological reactions. Seventy-six per cent of subjects with hypertension and a positive serology showed moderate or severe aortic dilatation. Comparable degrees of aortic dilatation were found in only 49 per cent of subjects without hypertension and with a negative serology.

Precise evaluation of the relative roles of syphilis and/or yaws in the production of aortic damage and dilatation in these subjects is impossible for several reasons: (1) it is impossible to determine accurately the relative incidence of yaws and syphilis from the clinical standpoint; (2) with respect to serology, it is also impossible to state what proportion of subjects now negative were positive in the past; (3) there is still much doubt as to whether $T$. pertenue may not produce visceral, and particularly cardiovascular, lesions comparable with those produced by $T$. pallidum.

An ætiological relationship between syphilis and hypertension has been asserted (Stoll, 1915; Harris, 1941) and denied (Fishberg, 1939). Comstock (1957) in an epidemiological study of blood 
pressure levels in a biracial community in the southern United States found higher levels of arterial pressure in negro subjects with a positive serology than in a group of the same race whose serology was negative. In the absence of common pathological effects of syphilis likely to produce an increase in blood pressure, he concluded that the association was not likely to be one of cause and effect, but that there may be a common factor or factors related to both hypertension and syphilis.

No correlation was found in our subjects, either in those with aortic dilatation or in their controls, between the levels of arterial pressure and the serological reactions. For reasons given above, no conclusions can be drawn from these data on the effect of syphilis per se on arterial pressure.

The Aetiology of Aortic Regurgitation. This is the commonest valvular lesion encountered in the University College Hospital of the West Indies (Tulloch, 1958). Its prevalence in those with aortic dilatation was 20 per cent in men and 7 per cent in women, findings which accord with clinical observations in Jamaica (Irvine and Tulloch, 1960) and elsewhere. It appears that there is a high incidence of aortic dilatation in the community which may form the reservoir for a large proportion of patients seen later in hospitals with decompensated aortic regurgitation. That it may occur on a background of arterial hypertension is clear in that amongst women with aortic regurgitation even diastolic pressures were higher than in their controls, and in men diastolic pressures were not significantly depressed, in spite of the valvular lesion (Table V).

Though hypertension seems to be an important factor in the production of aortic dilatation in both sexes, both hypertension and severe aortic dilatation are commoner in women, which suggests that another factor more marked in men, may be of significance in precipitating both the development of aortic regurgitation and its subsequent clinical deterioration, in subjects with aortic dilatation; this factor may be physical exertion.

The association of the more severe degrees of aortic dilatation and regurgitation with arterial hypertension seems to have been previously overlooked in Jamaicans. There are probably several reasons for this: (1) the associated hypertension is comparatively symptomless unless cardiac failure or vascular complications have occurred; (2) with the development of aortic incompetence severe enough to warrant hospitalization, the pre-existing hypertension is effectively obscured. (3) when hypertension and aortic aneurysm have been found together in Jamaica, it has been thought that this was due to the co-incidence of two common diseases.

The significance of aortic dilatation in the absence of aortic regurgitation remains to be determined but it is possible that planned programmes of case detection and effective treatment of the associated hypertension, even in the absence of significant symptoms, would considerably reduce the incidence and mortality of aortic regurgitation in Jamaica.

\section{SUMMARY AND CONCLUSIONS}

In an analysis of $208570 \mathrm{~mm}$. chest X-rays of subjects aged 35-64 from a rural population in Jamaica, 79 of the 995 men $(7.9 \%)$ and 92 of the 1090 women $(8.4 \%)$ showed some degree of aortic dilatation.

The clinical examination of these people and age and sex balanced control groups drawn by random methods from the same population revealed three main findings.

(1) Arterial pressure levels were consistently higher in the affected, than in the controls. (2) The condition was associated with aortic regurgitation in 20 per cent of men and 7 per cent of women. (3) Both aortic dilatation and arterial pressure in these subjects were apparently unrelated to their present serological status. Positive serological reactions were found in about 25 per cent of affected and controls.

The possible role of syphilis and/or yaws in association with hypertension in producing aortic dilatation is discussed.

A relationship between aortic dilatation, often gross, and hypertension has been demonstrated and this combination appears to have a high prevalence in West Indian negroes. Whatever the role of treponemal infection it is apparently not the most important single factor in the production of 
either the aortic dilatation, the associated hypertension, or the resulting aortic regurgitation. The significance of uncomplicated aortic dilatation, in terms of morbidity and mortality, remains to be determined by follow-up studies of these groups.

We wish to record our thanks to Dr. A. A. Peat, Chief Medical Officer, Ministry of Health, Jamaica, for the provision of facilities for the chest X-ray survey from which this study arose, and to Professor E. K. Cruickshank and Professor J. C. Waterlow, Department of Medicine, University College of the West Indies, and Professor A. L. Cochraine, Medical Research Council, Pneumoconiosis Reseach Unit, South Wales, for their encouragement and advice.

We gratefully acknowledge the assistance given by Professor Scott Thomson, Public Health Laboratory Service, Cardiff, Professor G. Bras, Department of Pathology, University College of the West Indies, Dr. J. I. Rerrie, lately Tuberculosis Officer, Kingston Chest Clinic, Dr. T. G. Morris and Mr. W. G. Clarke of the Medical Research Council Pneumoconiosis Research Unit, and Dr. Garcia and Nurse Carmen Atkinson of the Lawrence Tavern Government Dispensary.

These surveys could not have been carried out without the willing co-operation of the people of the Lawrence Tavern area and the energetic field work of the epidemiological team employed.

This work was supported by the Medical Research Council and a Colonial Development and Welfare Grant.

\section{REFERENCES}

Beerman, H., Nicholas, L., Schamberg, I. L., Greenberg, M. S., and Guthe, W. T. (1961). Arch. intern. Med., 107, 121. Cochrane, E. (1960). Report to Fifth Annual Scientific Conference for Medical Research in the British Caribbean, held in Jamaica, April 2nd-4th.

Comstock, G. W. (1957). Amer. J. Hyg., 65, 271.

Fishberg, A. M. (1939). In Hypertension and Nephritis, 4th ed. p. 611. Lea \& Febiger, Philadelphia.

Grant, L. S. (1956). West Ind. med. J., $5,97$.

Harris, H. C. (1941). Mil. Surgeon, 88, 642.

Irvine, R. A., and Tulloch, J. A. (1960). Report to Fifth Annual Scientific Conference for Medical Research in the British Caribbean, held in Jamaica, April 2nd-4th.

Johnston, H. (1959). Personal communication.

Kass, E. H., Miall, W. E., and Stuart, K. L. (1961). J. clin. Invest, 40, 1053.

Miall, W. E., Ling, J., Stuart, K. L., and Kass, E. H. (1962). Brit. med. J. In press. , and Rerrie, J. I. (1961). To be published.

Stoll, H. F. (1915). Amer. J. med. Sci., 150, 178.

Stuart, K. L., Schneckloth, R. E., Lewis, L. A., Moore, F. E., and Corcoran, A. C. (1962). Brit. med. J. In press. Thompson, W. B., Hudnut, H. B., Russo, P. E., Brown, F. R., and Mosley, K. T. (1961). J. Chr. Dis., $13,148$.

Tulloch, J. A. (1958). West Ind. med. J., 7, 169.

Wattley, G. (1960). West Ind. med. J., 9, 189. 